\title{
The Role of Customer Satisfaction in Increasing Customer Loyalty
}

\author{
Ati Arifiah Siswi ${ }^{\bowtie}$, Wahyono \\ Management Department, Faculty of Economics, Universitas Negeri Semarang, Semarang, Indonesia
}

\section{Article Information}

Article History:

Received January 2020

Approved February 2020

Published March 2020

\section{Keywords:}

Custemer Loyalty, Brand

Personality, Brand Repu-

tation, Price Fairness,

Customer Satisfaction.

\begin{abstract}
The purpose of this study is to determine the direct and indirect influence of brand personality, brand reputation and price fairness toward customer loyalty through customer satisfaction as an intervening variable. Customer satisfaction influence customers to make an loyal. The population in this research is customers Kukubima Energi. The total sample in this research is 115 respondents with purposive sampling technique through a likert scale. Methods of collecting data using questionnaires and documentation. Data analysis using classic assumption test and hypothesis test (t test and path analysis) with SPSS Statistics version 21 programs. Based on the hypothesis test, the results show that brand personality has a positive and significant effect on customer loyalty, price fairness has a positive and significant effect on customer loyalty, brand reputation does not has a positive and significant effect on customer loyalty, and customer satisfaction has a positive and significant effect customer satisfaction. Mediation test shows that positive emotion mediates the effect of brand personality, and price fairness on customer satisfaction.
\end{abstract}

\section{INTRODUCTION}

The economic development that occurred in Indonesia at this time forcing market players to be good at making strategies in anticipation of increasingly fierce competition (Fatona, 2010), Every company from time to time are always trying to provide satisfaction to its customers, because it means maintain satisfy even improve the business of the company (Permana, 2013). The company's focus today is increasingly focusing their marketing dimension to the customer.

Companies must be able to see what the most appropriate approach to customer behavior, so that by knowing the attitude of the customers then they are expected to continue to shop and loyal to the company (Rakhsha \& Majidazar, 2011).

One of the biggest challenges in business in the global era is to create and maintain custo- mer satisfaction and loyalty in order to get to a product. According to Mulyadi and Saktiawati, (2008) customer satisfaction increasingly necessary because consumers are increasingly easy to switch from one brand to another brand. Therefore, customer satisfaction is key to gaining customer loyalty (Suwono \& Sihombing, 2016)

Creating a strong relationship and closely with customers is the most important thing for the company and the key to long term success. Companies that can survive if it has the ability to provide customer satisfaction, it will have a positive impact on the company's long-term as well as short-term (Artanti, 2016).

Companies must be able to see what the most appropriate approach to customer behavior, so that by knowing the attitude of the customers then they are expected to continue to shop and loyal to the company (Rakhsha \& Majidazar,

(C) 2019 Universitas Negeri Semarang

\footnotetext{
Correspondence Address:

L2 Building, 1st Floor, Faculty of Economics, Universitas Negeri Semarang

Jalan Taman Siswa, Sekaran, Gunungpati, Semarang, 50229
}

E-mail: atiarifiahs@gmail.com 
2011). One of the biggest challenges in business in the global era is to create and maintain customer satisfaction and loyalty in order to get to a product. According to Mulyadi and Saktiawati, (2008), customer satisfaction increasingly necessary because consumers are increasingly easy to switch from one brand to another brand. Therefore, customer satisfaction is key to gaining customer loyalty (Suwono \& Sihombing, 2016).

Creating a strong relationship and closely with customers is the most important thing for the company and the key to long term success. Companies that can survive if it has the ability to provide customer satisfaction, it will have a positive impact on the company's long-term or short-term (Artanti, 2016). According to Hermawan Kertajaya (2004), the brand is the most important value in marketing. Products or services that have a brand can provide added value so that prices can be higher at the same product but the different prices (Farida, 2014), Therefore we need special strategies to cope with increasingly fierce competition. The way to be taken in creating customer loyalty that is by creating a brand personality, as most consumers get the brand personality of the products they use.

Aaker and Joachimstahler (2000) states that brand has characteristics that are broader than the product that is the image of the product, country of origin, company associations, brand personality, symbols and brand relationships / customers, in addition to the brand can deliver additional benefits such as the benefits of self-expression users and emotional benefits. Kotler and Armstrong (2006) explains that the rationale of the brand personality is that both human or brand has a personality, and humans as consumers tend to choose brands that suit his personality. Teimouri et al. (2016) found that brand personality has a relationship and a positive and significant impact on loyalty customers.

The result is contrary to research conducted by Kwong \& Candinegara, (2014) which states that there is a positive and significant correlation between the personality of the brand to customer loyalty. Besides having a direct relationship to the loyalty, brand personality also have the indirect effect through satisfaction. That suggested that brand personality also have the indirect effect through satisfaction. In the study conducted by Adinehfar et al. (2016) stated that the brand personality positive and significant impact on customer loyalty through customer satisfaction.

Other factors that also determine customer loyalty is the brand's reputation or the reputation of the brand. Brand reputation can be defined as the perception of quality associated with the name of the company (Aaker, 1991). Brand reputation can be developed not only through advertising but also influenced by the quality and performance of products. A good brand will be able to deliver benefits to customers, and the company can continue to maintain the existing advantages on the product (Ward, 2012).

A brand is said to have the reputation of the brand, relying on consumer opinion about the product. Companies can achieve the brand if the brand reputation can be known and accepted by the public, so that the brand can become widely known through the development of advertising and public relations are good (Rachman, 2016). Santosa et al. (2016) in his research say that the reputation is positive and significant impact on customer loyalty. While research by Fakhrudin, (2016) states that the reputation of the brand (brand reputation) there is a significant and positive relationship on customer loyalty.

In addition to brand personality, brand reputation is a factor in customer loyalty, fairness price is also a factor that affects customer loyalty. Based on a consumer's perspective, the price is often used as a indikator value when the price is linked to the perceived benefits of goods and services (Tjiptono, 2008).

Price is another factor driving consumers to purchase. Amryyanti and Cahya, (2012) defines the reasonableness of the price as something of an outcome assessment and how the process will get a result that is acceptable, and certainly in a fairness in the sense that it makes sense.

Wijaya and Nurcaya, (2017) stated that the price fairness has a positive and significant impact on customer loyalty. This is in line with research conducted by Ariastuti and Untoro, (2017) which shows that the price fairness has a positive and significant impact on brand loyalty. The above results different from study Amryyanti and Cahya, (2012) which states that the price of fairness there is no positive and significant impact on customer loyalty.

Industrial developments in the fields of pharmaceuticals and traditional medicines are now showing a very significant development. This is evidenced by the number of pharmaceutical products and traditional medicines manufactured by many companies in Indonesia, so the pharmaceutical industry and drug tradisiona cause competition to market their products to consumers. In this case the advantage PT Sido Muncul Tbk in competing indispensable of consumption of traditional drinks such as herbs seems to decline for some time. It is seen from 
the decline in sales of drinks stamina is on Sido Appear's flagship product is Kukubima Energy. Here is an Energy Kukubima sales data which has decreased since the last four years. Based on data from the Annual Report PT Sido Muncul Tbk known to decrease Kukubima Energy sale from 2015 to 2018 .

Table 1. Kukubima Sales Data

\begin{tabular}{lll}
\hline Year & Sale(Rp) & Percentage \\
\hline 2015 & Rp. 996.8 Billion & $19.7 \%$ \\
2016 & Rp. 963.2 Billion & $3.4 \%$ \\
2017 & Rp. 794.8 Billion & $17.5 \%$ \\
2018 & Rp. 815.90 Billion & $3.1 \%$ \\
\hline
\end{tabular}

Based on Table 1.2 it can be seen that the decline in sales Kuku Bima Energy PT Sido Muncul Tbk from 2015 until 2018. The highest sales occurred in 2015, which reached Rp.998,6 Billion and lowest sales occurred in 2017. By $2017 \mathrm{Kuku}$ Bima Energy sales of Rp. 794.8 billion and the number fell by $17.5 \%$ compared to 2016 which reached Rp. 963.2 bln. In 2018 an increase of Rp. 815.90 billion and that number was up $3.1 \%$ compared to 2017. It can be concluded that the sale Kukubima Energy from 2015 to 2018 experienced fluktuation.

In accordance with the above study, the researchers are interested in doing research related to the role of the factors that affect customer loyalty. Researchers chose satisfaction used as a mediator in the relationship between the factors that affect customer loyalty. According to $\mathrm{Mu}-$ lyadi and Saktiawati (2008) Customer satisfaction increasingly necessary because consumers are increasingly easy to switch from one brand to another brand, so the loyal behavior of consumers will be increasingly difficult to realize. Consumer satisfaction is the decisive factor in maintaining and developing the company (Kotler, 2006).

Several previous studies have shown a link between customer satisfaction and loyalty of customers. Results of research conducted by David and Prihandono (2012) shows that customer satisfaction is positive and significant impact on customer loyalty. The reason for choosing customer satisfaction as mediating variables are also supported by previous studies showing that brand personality, brand reputation and price fairness can affect customer loyalty through customer satisfaction (Gul, 2014; Adinehfar \& Gayem, 2016; Solar \& Nurcaya, 2017).
The purpose of this study is to determine the influence of brand personality, brand reputation, and price fairness on customer loyalty directly and indirectly as well as the influence of customer satisfaction on customer loyalty. This study uses the variables that never existed in this previous research. Research conducted by combining these variables in a single model.

\section{Hypothesis development \\ Brand Personality}

Brand personality is a specific mix of human nature that can be linked to a particular brand. Kotler and Keller (2009) defines brand personality as a mixture of certain human nature that can be combined with a particular brand. According to Wismiarsi and Purnama (2015) states that brand personality can be developed as a strategy to create customer loyalty. Research conducted by Farhat and Khan (2011), Then the hypothesis as follows:

H1: There is a significant positive effect on customer loyalty brand personality.

In addition, customer satisfaction as well as a mediator in influencing customer loyalty. Kotler \& Armstrong (2006: 140) explains the rationale of brand personality is that neither brand nor humans have personalities and humans as consumers tend to choose brands with a personality that fits his personality. Research shows that customer satisfaction has a direct influence on customer loyalty (Firmansyah and Prihandono 2018) Then the hypothesis as follows:

$\mathrm{H} 2$ : There was a significant positive effect of brand personality on customer loyalty through customer satisfaction.

\section{Brand Reputation}

Brand reputation refers to the opinion on whether or not and the reliability of a brand (Andriani 2015). Brands can be good or bad depends on the views of consumers who have been using the product. If consumers are satisfied on a brand it will affect the reputation of the brand (Azhari \& Arifin 2017)

Brand reputation have a significant direct effect on customer loyalty (Santosa et al., 2016) and have an influence on customer loyalty through customer satisfaction. Then the hypothesis as follows:

H3: There is a significant positive effect on customer loyalty brand reputation

$\mathrm{H} 4$ : There is a significant positive effect brand reputation customer loyalty through customer satisfaction. 


\section{Price Fairness}

One important factor in influencing customer satisfaction is the reasonableness of the price. Based on the price of consumer viewpoint is often used as an indicator of value when prices are linked as the perceived benefits of goods and services (Tjiptono 2008). According to Consuegra et al. (2007) fairness is defined as an assessment for an outcome and process in order to achieve a reasonable and acceptable. Price reasonableness based on a comparison of transactions involving different parties when deemed there is a difference, then the degree of similarity transaction is the most important element in the reasonableness of the price (Xia et al.,2004). Research shows that price fairness has a significant influence on customer loyalty (Asthma et.al., 2018) and price fairness has a significant influence on satisfaction (Wijaya \& Nurcaya 2017), Then the hypothesis as follows:

H5: There is a positive effect of price fairness on customer loyalty

H6: There was a significant positive effect of price fairness on customer loyalty through customer satisfaction

\section{Customer Satisfaction and Customer Loyalty}

Oktaviani 2014defines loyalty is a behavior that is performed by someone with decision making without being affected by competitors. Consumer loyalty is an attitude after the purchase, it's not necessarily arise (Herman, 2011). Research by Lam et al. (2004) stated that customer satisfaction is able to mediate the relationship between customer value and loyalty, as well as customer satisfaction and customer loyalty and have a significant mutual effects of each other. Customer satisfaction is a response to consumer behavior in the form of after-purchase evaluation of the goods and services that he felt and compared with expectations of consumers (Damayanti \& Wahyono 2015), According to Diputri (2015) Stated that the key to retaining customers is customer satisfaction. Previous research shows that customer satisfaction has a significant influence on customer loyalty (Wijayanti and Wahyono, 2015). Then the hypothesis is as follows:

H7: There is the influence of customer satisfaction on customer loyalty.

\section{METHOD}

This type of research used in this research is quantitative research. According to(Sugiyono, 2009) Quantitative research method can be interpreted as a method of research that is based on the philosophy of positivism, is used to examine the population or a particular sample, data collection using research instruments, and quantitative analysis / statistics, with the aim to test the hypothesis that has been set. In this study, the population used are all customers of Kukubima Energy in Semarang. Because the population is not known, then used the formula of iteration and obtained sample of 115 respondents.

This study used a technique nonprobability sampling (purposive sampling). This method is a sampling technique based on certain considerations which Kukubima Energy customers in Semarang who have purchased the product more than twice.

Data collection methods used in this research questionnaire method, the method of documentation. data analysis using descriptive analysis of the percentage, the classical assumption, hypothesis testing with statistical test $t$ and test path analysis. Data analysis using IBM SPSS Statistics software 23. Variables include the dependent variable, independent variable and intervening variables. The dependent variable in this study is a customer loyalty indicators: (1) Been repeated (Repeat Purchase / Visited) (2) Resistance to negative influences (Griffin, 2003; Kotler \& Keller, 2006). The independent variables include: Brand personality, Brand reputation and Price fairness. Brand personality measured by indicators (1)sincerity: (2) Excitemet: (3) competence: (4) ruggedness.

While brand reputation is measured by indicators (1) Widely (2) Reliability brand: (3) The identity positively about the brand: (4) image / brand image (Parthizgar et al 2005: Putro 2013). Variable price fairness is measured by indicators (1) the customer was paying a reasonable price on every purchase: (2) pricing policy is determined by the company is reasonable and acceptable to the customer: (3) the price received is an ethics: (4) conformity with quality products prices (Consuegra, 2007: Nurdiansah, 2013). The intervening variable in this study is customer satisfaction with the indicator (1) Expectation / expectations: (2) Interest of reuse: (3) willingness to recommend (Rida 2019: Tjiptono 2000).

\section{RESULT AND DISCUSSION}

\section{Normality Test}

The results of the normality test of variables brand personality, brand reputation, price fairness and customer satisfaction towards customer loyalty on the P-plot graph indicate the points spread around or follow the direction of the diagonal line, which means the data is normally distributed. Test for normality through the non-parametric statistical test Kolmogrov- Smir- 
nov (KS) which shows the data are normally distributed because Asymp values are obtained Sig (2-tailed) of $0.061>0.05$.

\section{Multicollinity Test}

The results of the multicollinity test showed that each independent variable had a value tolerance $>0.10$. Variable brand personality is 0,636 brand reputation is 0.940 , price fairness is 0.578 and customer satisfaction is 0.168 . Each independent variable has a value of Variance Inflantion Factor (VIF) $<10$. Variable brand personality is 1.578 , brand reputation is 1.064 , price fairness is 1.729 , and customer satisfaction is 1.462 . There is no multicollinearity between independent variables in the regression model.

\section{Heteroscedasticity Test}

Heteroscedasticity test results through scatterplot graphs, the points spread randomly both above and below the number 0 and the $\mathrm{Y}$ axis. Based on the results of the Glejser test all independent variables have a probability value sig. $>0.05$. Variable brand personality is 0.086 , brand reputation is 0.529 and price fairness is 0.404 and positive emotion is 0.058 . There are no interdependent variables between each other and heteroscedasticity does not occur.

\section{Hypothesis Test}

Table 2. Variable regression results brand personality, brand reputation, price fairness and customer satisfaction to customer loyalty

\begin{tabular}{llll}
\hline Model & Beta & T & Sig. \\
\hline Constant & & -1.021 & .310 \\
Brand Personality & .223 & 2.757 & .007 \\
Brand Reputation & .040 & .610 & .543 \\
Price Fairness & .296 & 3497 & .001 \\
Customer satisfaction & .366 & 4.704 & .000 \\
\hline
\end{tabular}

Dependent variable customer loyalty

\section{Effect of Brand Personality Toward Customer Satisfaction}

The results showed that brand personality had a positive and significant effect on impulse buying. $\mathrm{T}$ value of $2.757>1.981$ and sig value of $0.007<0.05$. H1 which states that brand personality has a positive and significant effect toward customer satisfaction be accepted. This means that the better implementing brand personality of Kukubima Energi, the greater consumers opportunity to do customer loyalty. This result is supported by previous research con- ducted by Farhat and Khan, (2011) that brand personality has a positive and significant effect toward customer satisfaction.

\section{Effect of Brand Reputation Toward Customer Loyalty}

The results showed that brand reputation had not a positive and significant effect on customer loyalty. $\mathrm{T}$ value of $0.610<1.981$ and sig value of $0.543>0.05$. H3 stating that brand reputation has not positive and significant impact on customer loyalty be accepted. This means that the more frequent brand reputation does not increase customer loyalty. These results support the research of Fakhrudin, (2016)that brand reputation has not a positive and significant effect on customer loyalty.

\section{Effect of Price Fairness Toward Customer Loyalty}

The results showed that sales promotion had a positive and significant effect on impulse buying. $\mathrm{T}$ value of $3.497>1.981$ and sig value of $0.001<0.05$. H5 stating that price fairness positive and significant impact on customer loyalty be accepted. This means that the more frequent price fairness that are given by Kukubima Energi, the more consumers will make customer loyalty.These results support the research of Wijaya \& Nurcaya, (2017) that price fairness has a positive and significant effect on customer loyalty.

\section{Effect of Customer Satisfaction Toward Customer Loyalty}

The results showed that sales promotion had a positive and significant effect on impulse buying. $\mathrm{T}$ value of $4.704>1.981$ and sig value of $0.000<0.05$. H7 stating that customer satisfaction positive and significant impact on customer loyalty be accepted. This means that the more frequent customer loyalty that are given by Kukubima Energi, the more consumers will make customer loyalty. These results support the research of Firmansyah \& Prihandono, (2012)t hat customer saticfaction has a positive and significant effect on customer loyalty.

\section{Path Analysis}

Table 3. Model 1 R Square

Model Summary

\begin{tabular}{lllll}
\hline Model & $\mathbf{R}$ & $\begin{array}{l}\mathbf{R} \\
\text { Square }\end{array}$ & $\begin{array}{l}\text { Adjusted } \\
\text { R Square }\end{array}$ & $\begin{array}{l}\text { Std. Error } \\
\text { of the Esti- } \\
\text { mate }\end{array}$ \\
\hline 1 & $.562 \mathrm{a}$ & .316 & .297 & 1.47999 \\
\hline
\end{tabular}


Based on the data in Table 4 in mind that the value of $R$ Square is 0,316 . The $R 2$ value can be used to calculate the value of e2 by the formula: $e_{1}=\sqrt{1-R^{2}}$ maka $e_{2}=\sqrt{1-0,316}=0,827$

Table 4 Table Model 1 The Effect of brand personality, brand reputation, and price fairness toward customer satisfaction.

\begin{tabular}{lcll}
\hline Model & beta & T & Sig. \\
\hline Constant & & 4.339 & .000 \\
brand personality & .275 & 2.894 & .000 \\
brand reputation & -.061 & -.753 & .453 \\
Price fairness & .370 & 3.807 & .000 \\
\hline Dependent variables: Y1 customer satisfaction
\end{tabular}

Based on Tables 3 and 4 it can be seen the regression equation as follows:

Customer satisfaction $=(0.275) \mathrm{X} 1+(-0.061) \mathrm{X} 2$ $+(0.370)+0.827 \mathrm{X} 3$

Every increase brand personality will be followed by an increase of customer satisfaction (0.275) when the other variables are assumed to remain. Each of the increase will be followed by increase in the brand's reputation for customer satisfaction $(-0.061)$ when the other variables are assumed to remain. Then, any increase in price will increase the fairness of $(0.370)$ when the other variables are assumed to remain.

Table 5. Model $1 \mathrm{R}$ Square

\begin{tabular}{lllll}
\multicolumn{4}{l}{ Model Summary } \\
$\begin{array}{l}\text { Mod- } \\
\text { el }\end{array}$ & $\mathbf{R}$ & $\begin{array}{l}\mathbf{R} \\
\text { Square }\end{array}$ & $\begin{array}{l}\text { Adjusted } \\
\text { R Square }\end{array}$ & $\begin{array}{l}\text { Std. Error of } \\
\text { the Estimate }\end{array}$ \\
\hline 1 & $.738 \mathrm{a}$ & .544 & .527 & 1.34560 \\
\hline
\end{tabular}

Predictors: (constant), Y1, X3, X2, X1

Based on data in Table 6 is known that the value of $R$ Square is 0.527 . The $R 2$ value can be used to calculate the value of e 2 by the formula: $e_{2}=\sqrt{1-R^{2}}$ maka $e_{2}=\sqrt{1-0,544}=0,675$

Table 6. The Effect of brand personality, brand reputation, and price fairness toward customer satisfaction.

\begin{tabular}{lccc}
\hline Model & beta & T & Sig. \\
\hline Constant & & $-1,021$ & .310 \\
brand personality & .223 & 2,757 & .007 \\
brand reputation & .040 & .610 & .543 \\
Price fairness & .296 & 3,497 & .001 \\
Kepuasan Pelanggan & .366 & 4,704 & .000 \\
\hline Dependent variables: Y2 customer loyalty
\end{tabular}

Based on Table 5 and Table 6 it can be seen the regression equation as follows:

Customer Loyalty $=(0.223) \mathrm{X} 1+$ $(0,040) \mathrm{X} 2+(0,296) \mathrm{X} 3+(0.366) \mathrm{Y} 1+0.675$ (2)

Every of the increase brand personality will not be followed by increase customer loyalty by 0.223 when other variables are assumed to remain. Each of the increase brand reputation will be an increase in customer loyalty amounted to 0,040 when other variables are assumed to remain. Every occurrence of fairness price hike will be an increase in customer loyalty 0.366 when other variables are assumed to remain. Each an increase in customer satisfaction will be followed by increase customer loyalty by 0.366 when other variables are assumed to remain.

Based on the calculation of the regression equation, it can be concluded regression research as follows:

Customer satisfaction $=(0.275) \mathrm{X} 1+$ $(-0.061) \mathrm{X} 2+(0.370)+0.827 \mathrm{X} 3$

Customer loyalty $=(0.223) \mathrm{X} 1+(0,040)$ $\mathrm{X} 2+(0,296) \mathrm{X} 3+(0.366) \mathrm{Y} 1+0.675$

\section{Effect of Brand Personality Toward Customer Loyalty Through Customer Satisfaction}

The the direct effect of brand personality on customer loyalty $\left(\mathrm{B}_{1}\right)$ is 0.223 . The indirect effect of brand personality to customer loyalty through a customer satisfaction is calculated by multiplying coefficient lines brand personality $\left(\mathrm{B}_{2}\right)$ with a path coefficient customer satisfaction (B7), namely $(0.275) \times(0.366)=0.101$. The total effect of the path coefficient is by adding up the direct effect and indirect effect of the variable, brand personality namely $\mathrm{B}_{1}+\left(\mathrm{B}_{2} \mathrm{XB}_{7}\right)=0.223+(0.275)$ $\mathrm{x}(0.366)=0.324$.

The results of the total effect indirect

coefficient of variables brand personality on customer loyalty through customer satisfaction is equal to 0.324 . While the path coefficient of the direct influence of brand personality on customer loyalty is 0.223 . This means that the total effect of the indirect path coefficient $>$ the effect of the direct path coefficient. Then $\mathrm{H}_{2}$ which states brand personality a positive and significant effect on customer loyalty through customer satisfaction is received. That means customersatisfaction is able to mediate the effect of brand personality with customer loyalty.

This result is supported by Sanjaya et al. (2016) research that brand personality has a positive and significant effect on customer loyalty through customer satisfaction. 


\section{Effect of Brand Reputation Toward Customer Loyalty Through Customer Satisfaction}

The direct effect of brand reputation on customer loyalty $\left(\mathrm{B}_{3}\right)$ is 0.040 . The indirect effect of brand reputation on customer loyalty through customer satisfaction is calculated by multiplying the path coefficient of brand reputation $\left(\mathrm{B}_{4}\right)$ by the path coefficient customer satisfaction $\left(\mathrm{B}_{7}\right)$, namely $(-0.061) \times(0.366)=-0.022$. The total influence of the path coefficient is to add up the direct effect and indirect effect of the variable, brand reputation namely $\mathrm{B}_{3}+\left(\mathrm{B}_{4} \times \mathrm{B}_{7}\right)=$ $0.040+(-0.061) \times(0.366)=0.018$.

The results showed that brand reputation influences customer loyalty through customer loyalty. The results of this study are proven by the total effect of the indirect path coefficient $0.018<0,040$ the effect of the direct path coefficient 0.040 . Then $\mathrm{H} 4$ indicates brand reputation effect on the customer loyalty through customer satisfaction received. This means that customer satisfaction has not influence of brand reputation on customer loyalty.

The results of this study are supported by Kurniawan, (2017) research that brand reputation has not a positive and significant effect on customer loyalty through customer satisfaction.

\section{Effect of Price Fairness Toward Customer Loyalty Through Customer Satisfaction}

The direct influence of price fairness on customer loyalty $\left(\mathrm{B}_{5}\right)$ is 0.296 . The indirect effect of price fairness on customer loyalty through positive emotion is calculated by multiplying the path coefficient of price fairness $\left(\mathrm{B}_{6}\right)$ with the path coefficient customer satisfaction $\left(\mathrm{B}_{7}\right)$, namely $(0.370) \times(0.366)=0.135$. The total influence of the path coefficient is to add up the direct effect and indirect effect of thevariable, shopping lifestyle namely $\mathrm{B}_{5}+\left(\mathrm{B}_{6} \mathrm{XB}_{7}\right)=0.296+(0.370)$ $\mathrm{x}(0.366)=0.431$.

The results showed that price fairness influences impulse buying through customer satisfaction. The results of this study are evidenced by the total effect of the indirect path coefficient $0.431>$ the effect of the direct path coefficient 0.296 . So that $\mathrm{H}_{6}$ stating price fairness influence on customer loyalty through customer satisfaction received. This means that customer satisfaction is able to mediate the influence of price fairness on customer loyalty.

This result is supported by Ariastuti and Untoro (2017) research that price fairness has a positive and significant effect on customer loyalty through customer satisfaction.
Based on the discussion above, the full model path analysis figure is as follows:

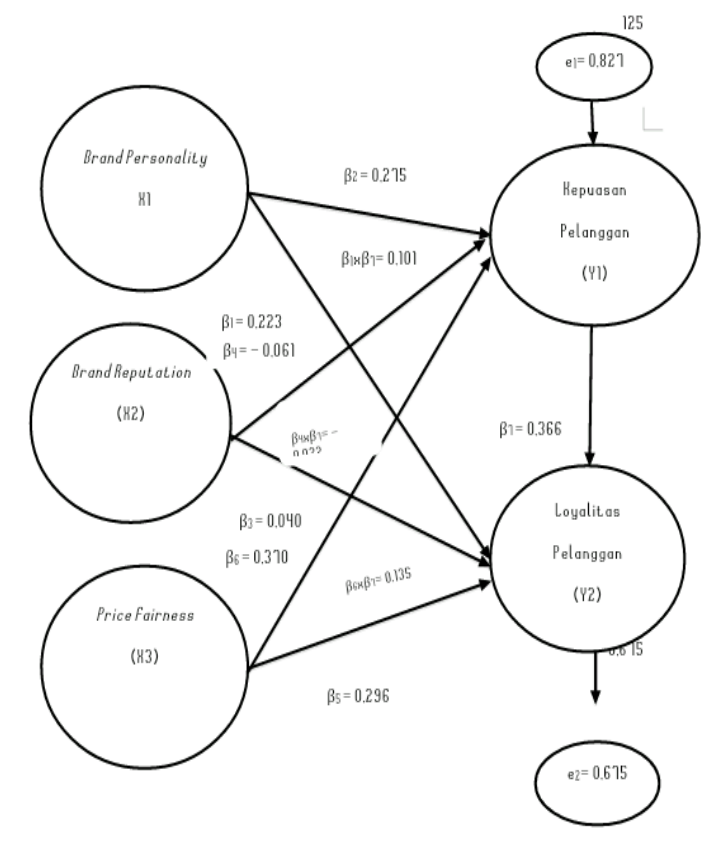

Figure 1. Full model path analysis

\section{CONCLUSION AND RECOMMENDATION}

Based on the results of research and discussion of the conclusions of this study are:

Brand personality significant positive effect on customer loyalty. It shows that the brand personality into consideration the customers to remain loyal to the product. So the higher / ride brand personality, it can increase customer loyalty.

Brand personality significant positive effect on customer loyalty through customer satisfaction. Customer satisfaction is able to mediate between the brand personality influence on customer loyalty. The stronger and better energy Kukubima brand personality will influence customer satisfaction getting better, then customer satisfaction will affect customer loyalty.

The better brand reputation has not significant positive effect on customer loyalty Kukubima Energy. It is caused by several factors: customers do not consider the reputation of the brand and are not concerned with the company's brand popularity and they only pay attention to the quality of the product, so that it meets their needs brand reputation significant positive effect on customer loyalty through customer satisfaction.

Customer satisfaction successfully mediate brand reputation on customer loyalty. Thus, the better brand reputation, the better customer satisfaction, so that customer satisfaction will increase customer loyalty become better. 
Price fairness significant positive effect on customer loyalty. This shows that the price of fairness into consideration the customers to remain loyal to Kukubima Energy. This means that the higher better price Energy Kukubima fairness, the higher better customer loyalty.

Price fairness significant positive effect on customer loyalty through customer satisfaction. Customer satisfaction is able to mediate between the price fairness influence on customer loyalty. The better price Kukubima Energi fairness, it will affect customer satisfaction getting better and better, so that customer satisfaction will increase customer loyalty become better.

Based on the results of research and discussion of the suggestion from this study are as follows:

The research and discussion shows that brand personality and price fairness positive and significant impact on customer loyalty. The higher and better brand personality and price fairness owned by Kukubima Energy, It will make customers more satisfied and loyal to Kukubima Energy. In addition, the brand has a proven reputation and negatively influence no significant effect on customer loyalty.

Customer satisfaction is also shown to have an important role as an intervening variable in the form of brand personality, brand reputation and price fairness on customer loyalty. This means that customer satisfaction is able to mediate the effect of brand personality, brand reputation and price fairness on customer loyalty Kukubima Energy. If the brand personality, brand reputation and price fairness is getting better, it will affect the Energy Kukubima increasing customer loyalty.

Suggestions for the company are: (1) PT Sido Muncul Tbk is expected to keep the brand personality who has been there, and further improve the quality of products optimized through innovation by increasing the durability and product benefits to customers, so that customers will remain loyal to the company's products , (2) PT Sido Muncul Tbk further enhance the brand's reputation so Kukubima Energy dn advertising by developing good public relations so that customers can benefit from Kukubima Energy (3) Company in creating the reasonableness of the price should be accepted by the consumer and with regard to price increases and price comparisons with competitors.

For further research, it is advisable to consider other variables that may affect customer loyalty, such as brand trust and brand competence.

\section{REFERENCE}

Aaker, J. L. (1997). Dimensions of Brand Personality. Journal of Marketing Research, 34, 347-356. Re- trieved from http://www.haas.berkeley. edu/ groups/finance/Papers/Dimensions of BP JMR 1997.pdf

Aaker D., 1991, Brand Equity, The free press, New york NY

Aaker, David and Erich Joachimsthaler. 2000. Brand Leadership. New York: The Free Press

Adinehfar, A. R., Gayem, A., Gulf, P., Branch, I., \& Azad, I. (2016). Impact of Brand Personality on Satisfaction and Loyalty of Pact of Brand Personality on Satisfaction and Loyalty of Consumers (Case Study: Luxury Brands of Watches in the City Consumers (Case Study: Luxury Brands of Watches in the City Isfahan). Journal of Fundamental and Applied Sciences, 8(Special Issue), 462-477.

Adi, R. P. (2013). Pengaruh Kualitas Produk dan Kewajaran Harga terhadap Loyalitas dengan Kepuasan Konsumen sebagai Variabel Intervening. Management Analysis Journal, 2(1), 110115.

Amryyanti, R., \& Cahya, I. P. G. S. K. N. (2012). Pengaruh Kualitas Layanan, Produk, dan Kewajaran Harga terhadap Kepuasan dan Loyalitas Pelanggan pada Lnc Skin Care Singaraja. EJurnal Ekonomi dan Bisnis Universitas Udayana, 22-29.

Ariastuti, I., \& Untoro, W. (2017). Pengaruh Manajemen Hubungan Pelanggan dan Kewajaran Harga terhadap Loyalitas Merek dimediasi oleh Kepuasan Konsumen. Jurnal Wawasan Manajemen, 5, 242-257.

Aryani, Dwi dan Febrina Rosinta. 2010. "Pengaruh Kualitas Layanan terhadap Kepuasan Pelanggan dalam Membentuk Loyalitas Pelanggan". Bisnis dan Birokrasi, Jurnal Ilmu Administrasi dan Organisasi, 17(2), 114-126.

Asma, S., Baha Dine, M. S., Wafaa, B., \& Redouan, A. (2018). The Effect of Perception Quality/ Price of Service on Satisfaction and Loyalty Algerians Customers Evidence Study Turkish Airlines. International Journal of Economics \& Management Sciences, 07(1), 1-6.

Azhari, R., Arifin, R., \& Penelitian, A. (2017). Pengaruh Dimensi Kualitas Produk dan Reputasi Kepuasan Konsumen sebagai Variabel Intervening di Starbucks Malang Cabang Mall City Point Dieng. Jurnal Ilmiah Riset Manajemen, 64-80.

Cintya Damayanti, W. (2015). Pengaruh Kualitas Produk, Brand Image terhadap Loyalitas dengan Kepuasan sebagai Variabel Intervening. Management Analysis Journal, 4(3), 236-251.

David. (2018). Pengaruh E-Service Quality terhadap Loyalitas Pelanggan melalui Kepuasan Pelanggan pada Transportasi Online Grab. Petra International Journal of Business Studies, 6(2).

David Firmansyah, D. P. (2012). Pengaruh KualitasPelayanan dan Perceived Value terhadap Loyali- 
tas Pelanggan dengan Kepuasan. Manage- ment Analysis Journal, 1(2), 120-128.

Fakhrudin, A. (2016). Pengaruh Performance Quality, Reputasi Merek dan Kepuasan Pelanggan terhadap Loyalitas Merek. Jurnal Manajemen Dirgantara, 7(1), 65-83.

Fandy Tjiptono. 2002. Strategi Pemasaran. Edisi II. Yogyakarta: Andi Offset.

Farhat, R., \& Khan, B. M. (2011). Importance of Brand Personality to Customer Loyalty : a Conceptual Study Importance of Brand Personality to Customer Loyalty : A Conceptual Study. International Journal of Research in Commerce and Management.

Griffin, Jill, 2003. Customer Loyalty: Menumbuhkan dan Mempertahankan Kesetiaan Pelanggan, Erlangga, Jakarta.

Gul, R. (2014). The Relationship between Reputation, Customer Satisfaction, Trust, and Loyalty. Journal of Public Administration and Governance, 4(3), 368-387.

Hermawan, B. (2011). Pengaruh Kualitas Produk terhadap Kepuasan, Reputasi Merek dan Loyalitas Konsumen Jamu Tolak Angin Pt. Sido Muncul. Jurnal Manajemen Teori dan Terapan, 2(2), 9-17.

Hermawan Kerjaya. 2004. On Brand. Bandung: PT Mizan Pustaka

Ika Wahyu Wijayanti, W. (2015). Pengaruh Kualitas Pelayanan, Persepsi Harga dan Nilai Pelanggan terhadap Loyalitas Konsumen Melalui Kepuasan Pelanggan sebagai Variabel Intervening. Management Analysis Journal, 4(1), 50-57.

I Made Nugraha Santosa, Ni Wayan Sri Suprapti, I. G.

A. K. G. (2016). Pengaruh Kualitas Jasa terha- dap Kepuasan, Reputasi Merek dan Loyalitas Pengguna Kartu Sim Prabayar Telkomsel (Stu- di pada Segmen Remaja di Kota Denpasar). E- Jurnal Manajemen Unud, 8, 2491-2516.

Kartajaya on Marketing. Jakarta: Gramedia Pustaka Utama.

Kotler, Philip. 2007. Manajemen Pemasaran. Jilid 1 Edisi kesebelas. Indonesia: PT. Indeks.

Kotler, Philip, Keller dan Kevin Lane. 2006. Marketing Management. Pearson International Edition. New Jersey: Pearson Prentice Hall.

Kotler, Philip. Keller, K Lane, 2009. Manajemen Pemasaran. Edisi 13. Jilid 1 dan 2. Jakarta: Erlangga

Lam Yin Shun, Venkatesh, S., Erramilli Krishna M., \& Bvsan, M. (2004). Customer Value, Satisfaction, An Illustration From a Loyalty, and Switching Costs: Business-to-Business Ser. Journai of the Academy of Marketiag Science, 32, 293-311.

Kwong, M. Z., \& Candinegara, I. (2014). Relationship between Brand Experience, Brand Personality, Consumer Satisfaction, and Consumer Loyalty of DSSMF Brand. IBuss Management, 2(2), 89- 98.

Martín-Consuegra, D., Molina, A., \& Esteban, Á. (2007). An Integrated Model of Price, Satisfaction and Loyalty: an Empirical Analysis in the Service Sector. Journal of Product and Brand Management, 16(7), 459-468.

Muhammad Shohibur Rida, W. (2019). Pengaruh Kualitas Layanan, Perceived Value, dan Experiential Marketing terhadap Loyalitas Pelanggan melalui Kepuasan Pelanggan. Management Analysis Journal, 1-14.

Mulyadi, H., \& Saktiawati, D. (2008). Pengaruh Brand Personality terhadap Loyalitas Pelanggan Shampo Sunsilk (Survei pada mahasiswi FPIPS UPI Bandung Angkatan 2004-2006). Journal of Business Management \& Entrepreneur Education, 7(13), 20-32. 